\title{
Work related values and attitudes in Central and Eastern Europe*
}

Agnes Borgulya, Judit Hahn**

After the shift from centrally planned to market economies, CEE countries experienced significant changes in the world of work. Full employment was replaced by a distortion in labour markets, a rapid rise in unemployment and intensive labour emigration. The following questions are discussed: (1) Can the people in CEE countries be characterized by similar work-related values? (2) Is there any diversity in attitudes towards superiors in the transition countries? To answer these questions, findings of the European Values Study are used. The comparison of data from fourteen CEE countries shows that, concerning workrelated values, two groups of countries can be differentiated. The analysis of attitudes towards one's superior also suggests the lack of a homogenous Eastern European cluster.

Nach dem Beginn des Übergangs von der Zentralverwaltungs- zur Marktwirtschaft hat sich die Arbeitswelt in den MOE-Ländern dramatisch verändert. Die frühere Vollbeschäftigung wurde durch den Zusammenbruch des Arbeitsmarktes abgelöst, was zu hohen Arbeitslosenraten und nachher zu einer Arbeitsmigration geführt hat. In diesem Beitrag wir die Antwort auf folgende Frage gesucht: Haben die Arbeitnehmer in den untersuchten vierzehn MOELändern nach den Wertänderungen gleiche arbeitsbezogene Werte und gleiche Attitüden zu ihren Vorgesetzten? Um diese Fragen beantworten zu können, stützen sich die Verfasser auf die Datei der internationalen Erhebung European Values Study. Auf Grund der arbeitsbezogenen Werte konnten zwei Gruppen unterschieden werden. Die Analyse der Attitüde zum Vorgesetzten hat zum Vorschein gebracht, dass die untersuchten MOE-Länder in dieser Hinsicht nicht homogen sind.

Keywords: Work-related values, attitudes, Central and Eastern Europe, European Values Study

* Manuscript received: 04.07.07, accepted: 20.05.08 (1 revision)

** Agnes Borgulya, Ph.D., Faculty of Business and Economics, University of Pecs. Main research areas: Cross-cultural communication and management. Corresponding address: borag@ktk.pte.hu.

Judit Hahn, Ph.D. Student, Faculty of Business and Economics, University of Pecs. Main research areas: Sociolinguistics and intercultural communication. Corresponding address: hahn@ktk.pte.hu. 


\section{Changes in the world of work in the transition countries}

Back in the 1990's, textbooks on intercultural cooperation and communication, which set the standard for that time, painted a simplified picture of the macroeconomic, national, business and organizational culture of CEE countries. Harris and Moran, for example, wrote the following in a book published in 1996: "After decades under rigid Communist control, East Germany (now united with Germany), Poland, Czechoslovakia, Hungary, the disintegrating Yugoslavia, Romania, Bulgaria and Albania, as well as the CIS itself ... are left with exhausted labour reserves and high unemployment, ill-prepared and unproductive workers, out-of-date machinery and plants. In addition to the severe shortage of food and consumer goods, these nations are devastated by a frightful legacy of environmental pollution, ecological and economic ruin, as well as a collapsing infrastructure." (Harris/Moran 1996:326-327). Such an observation is not surprising: in the 1990's there were few thorough analyses on the business culture of the former Eastern Block, also known as the COMECON countries.

After the transition from centrally planned to market-based economies, CEE countries experienced significant changes in the world of work. Full employment, a fundamental feature of centrally planned economies, disappeared. The transition led to a distortion in labour markets. Over the 1990's labour market trends showed a high rate of long-term unemployment, accompanied by large regional disparities. Particularly hard-hit groups were the young, the disabled, low-skilled workers and certain ethnic minorities. The exodus of the workforce to foreign countries intensified, which resulted in 685,200 new Member State nationals employed in the EU15 between 2004 and 2006 (Traser/Venables 2008).

These trends had two consequences. On the one hand, work-related values were affected by the appearance of unemployment in the CEE countries. People had to face unemployment, job insecurity and the loss of regular income, which not only decreased living standards, but also made borrowing from banks more difficult. On the other hand, labour migration and the formation of subsidiaries by multinational enterprises in the transition countries put an end to the monocultural feature of workplaces, causing cultural conflicts.

The authors aim to conduct a comparison among fourteen CEE countries ${ }^{1}$ by focusing on values and attitudes related to work. The following main questions

1 The Eu-14 were chosen from the "Source book of the 1999/2000 European Values Study Survey" (Halman 2001) These countries are: Belarus $=$ BY, Bulgaria $=$ BG, Croatia $=$ HR, Czech Republic $=$ CZ, Estonia $=$ EE, Hungary $=$ HU, Latvia $=$ LV, Lithuania $=$ LT, Poland $=\mathrm{PL}$, Romania $=$ RO, Russia $=$ RU, Slovakia $=$ SK, Slovenia $=$ SI, Ukraine $=$ UA. Some Eastern European countries (e.g. Albania, Serbia etc.) did not take part in the survey. The abbreviations used are those found in the "Source book" (Halman 2001). 
thus naturally arise: (1) Can people in CEE countries be characterized by similar work-related values after the transition? (2) Is there any diversity in attitudes towards superiors in the transition countries? (3) Concerning the values analysed, can these countries be regarded as a homogenous cluster in Europe? What is new about this paper is that it relies on the findings of the third wave of the European Values Study, which was carried out in 1999/2000 in all examined countries at the same time using the same method and the same questionnaire.

\section{Work-related values in CEE}

The European Value Study (EVS), a large-scale cross-national and longitudinal research project on fundamental values in Western societies was initiated by researchers at Tilburg University and Leuven Catholic University at the end of the 1970's. Their goal was to empirically investigate the main fundamental value patterns of Europeans. The first wave of surveys took place in 1981. When Ronald Inglehard, a researcher at Michigan University joined, overseas institutes were also participating in the study. Thus, the World Value Survey was born. In 1990 a new study was completed to measure the changes that took place since then. This time all countries in the European Community, except for Greece, took part in the study, as well as some Eastern European and some Scandinavian countries. The third wave of surveys took place in 1999/2000, focusing on the same questions as before. These are the following: the importance of the most important spheres of life (e.g. family, work, religion), social questions, politics, environmental awareness of society, and other questions of morality. The attitudes towards other groups, such as immigrants and ethnic minorities, within the given society were also examined. The third wave of EVS took place in 32 countries of Europe and analyzed the questionnaires of 39,797 participants and, along with the results of WVS, it encompasses the results of the whole world (Arts et al. 2003; Halman 2001). To the best of our knowledge this is the first large scale survey on values that was commissioned by CEE countries and by Western European countries at the same time.

Work-related values represent a part of people's value scale that constitutes the basis for their everyday behaviour, decisions and interactions. Values related to different life spheres are not independent of one another: loyalty, motivation or performance at work, for example, are also affected by values concerning family, friends, free time, religion and even politics. By comparing the importance of work to other areas of life in the next section, we portray the main characteristics of people's value scales in the CEE countries 


\section{The importance of family, work, friends, leisure time, religion and politics}

To examine the ranking of work among other life spheres regarding its importance to Europeans, we provide an analysis of the value-judgements given by the respondents on the importance of family, work, friends, leisure time, religion and politics. For this reason we use the average data of 33 European countries $(\mathrm{Eu}-33)^{2}$.

Figure 1. The most important life spheres in Europe (33 countries) ${ }^{3}$

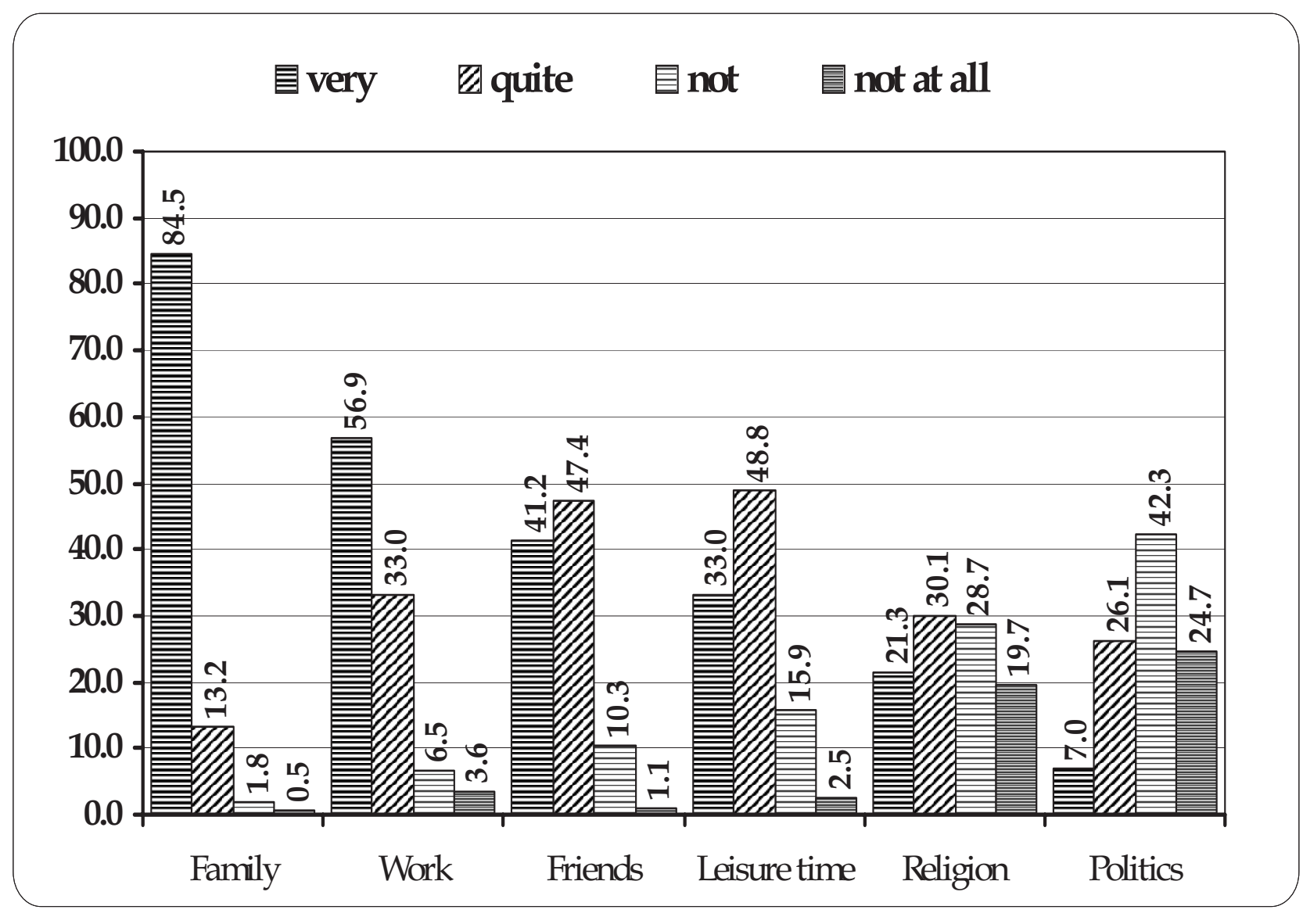

Source: EVS Source Book 1999/2000

2 The Eu-33 are: Austria $=$ AT, Belarus $=$ BY, Belgium $=$ BE, Bulgaria $=$ BG, Croatia $=$ $\mathrm{HR}$, Czech Republic $=\mathrm{CZ}$, Denmark $=\mathrm{DK}$, Estonia $=\mathrm{EE}$, Finland $=$ FI, France $=$ FR, Germany $=$ DE, Great Britain $=$ GB, Greece $=$ GR, Hungary $=$ HU, Iceland $=$ IS, Ireland $=$ $\mathrm{IE}$, Italy $=\mathrm{IT}$, Latvia $=\mathrm{LV}$, Lithuania $=\mathrm{LT}$, Luxembourg $=\mathrm{LU}$, Malta $=$ MT, Netherlands $=\mathrm{NL}$, Northern Ireland $=\mathrm{N}$-IE, Norway $=\mathrm{NO}$, Poland $=\mathrm{PL}$, Portugal $=\mathrm{PT}$, Romania $=$ RO, Russia $=$ RU, Slovakia $=$ SK, Slovenia $=$ SI, Spain $=$ ES, Sweden $=$ SE, Ukraine $=$ UA.

3 Data of all graphs are selected from the huge database of EVS third wave, and represented in graphs by the authors. In the analysis of the data, the authors round the numbers to integers in the text. 
As shown in Figure $1^{4}$, family is extremely important to Europeans (Eu-33). Out of all participants in EVS (over 40,000) 84\% considered family was 'very important' in life, and only $0.5 \%$ chose 'not at all important'. Comparing the results of each country, there is only a slight difference between the choices in Non-CEE and CEE countries. From the six life spheres, Europeans placed work second behind family; it is 'very important' to $58 \%$ on average, while 'not at all important' to only $3.5 \%$. Friends, with an average of $40 \%$ are also important to Europeans: this sphere ranked higher in the scale of values than leisure time or religion. Religion was fifth with an average of $21 \%$. The two extremes (Maltese $67 \%$, the Czechs 7\%) reflect high deviation. The least important category proved to be politics: only $7 \%$ of Europenas found it 'very important'.

\section{The importance of work}

A closer look at the importance of work in each European country reveals that people in Eastern Europe and Malta are more likely to consider work 'very important' than in Northern and Western Europe.

Figure 2. The importance of work in Eastern Europe

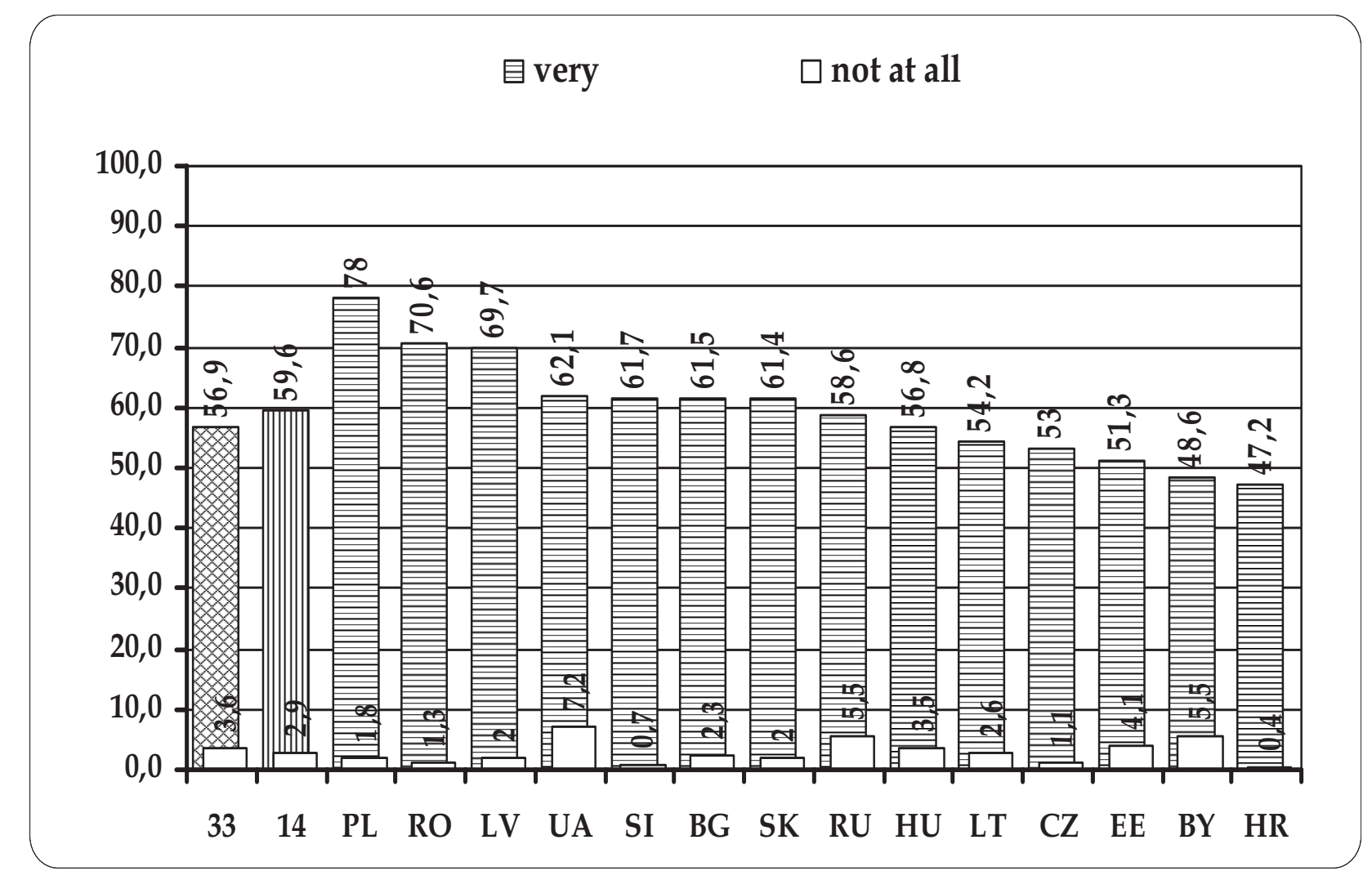

4 Data of all graphs are selected from the huge database of EVS third wave, and represented in graphs by the authors. In the analysis of the data the numbers were rounded to integers in the text. 
In Poland, Romania and Latvia work ranks much higher than the European average of $58 \%$. Also above the average are Ukraine, Slovenia, Bulgaria and Slovakia, which means altogether seven out of fourteen CEE countries. (See Figure 2) The background reasons for the attitude towards work are too complex to be analysed here in detail. Attitude to work can be determined by personal, social, cultural, micro- and macroeconomic factors. The level of incomes, the savings of families, the flexibility of the labour market, the operation of the unemployment benefit system etc. can all have their effect. It should be noted that in the late 90's unemployment rates in CEE counties were still higher than in the EU, and in 2000 they were above 10\% (in Poland 16.6\%), except for the Czech Republic, Hungary and Slovenia according to national surveys of labour. In many cases, the high rate of unemployment is likely to account for the figures exceeding the European average in Figure 2.

Figure 3. Importance of 'good pay' and 'pleasant people'

\section{Good pay}

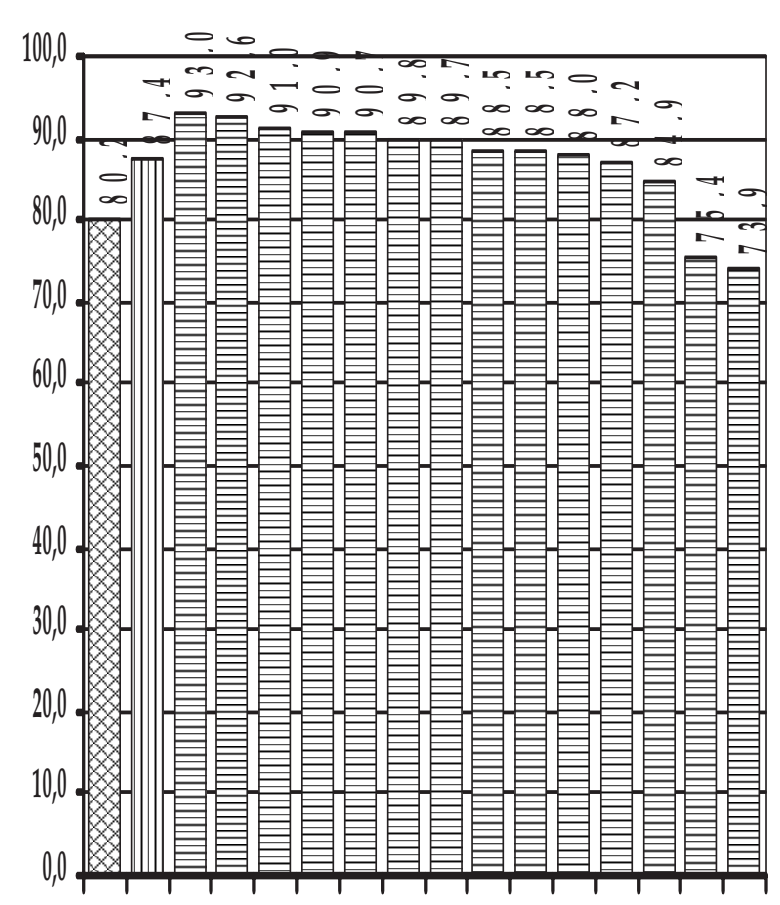

33 14 PL LT SK BG RO RU HU EE UA BY SI HR LV CZ

\section{Pleasant people}

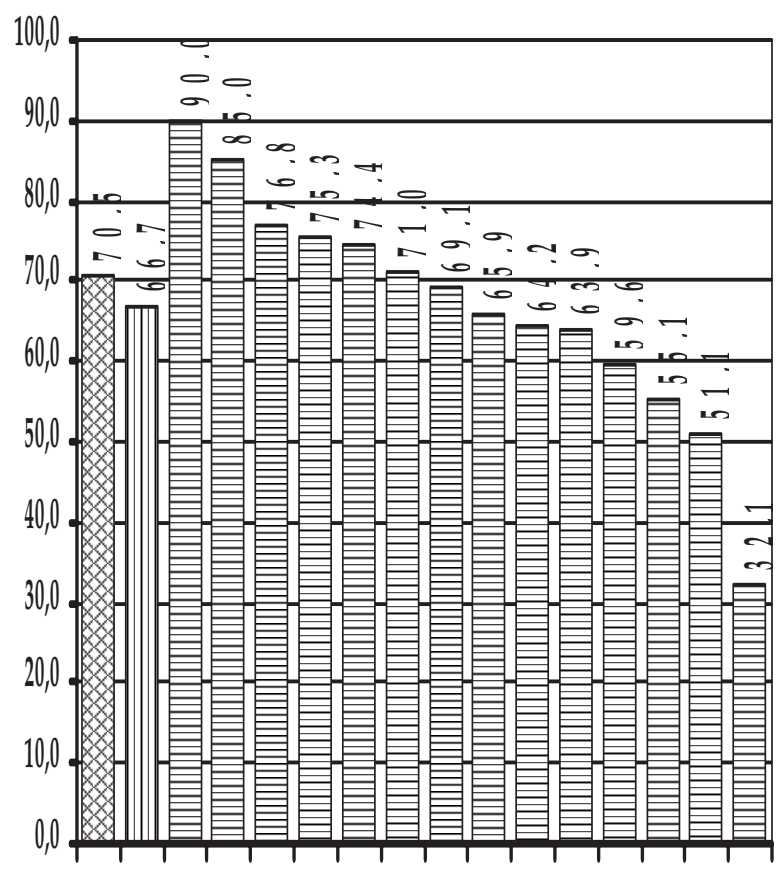

33 14 SI HU HR RO PL EE BY UA BG CZ LT RU SK LV 


\section{Work-related value preferences}

Work-related value preferences do not only influence the way how employees can be attracted, kept and motivated by a company, but may also lead to tensions and cultural conflicts at the workplace. In this section we examine which aspects of work are especially important to CEE employees. The EVS listed fifteen benefits of work and workplace about which the participants gave their opinions. These are 1. good pay, 2. pleasant people, 3. not too much pressure, 4. good job security, 5. good chances for promotion, 6. job respected by people in general, 7. good hours, 8. opportunity to use initiative, 9. job useful for society, 10. generous holidays, 11. meeting people, 12. job in which you can achieve something, 13. responsible job, 14. interesting job, 15. job that matches one's abilities.

Figure 3 demonstrates that on average the most important of all aspects for Europeans is good pay, which means that more than $80 \%$ of participants responded that good pay is 'very important' in a job.

It should be noted that the wish for high wages and salaries is especially strong in CEE countries: their average accounts for $87 \%$. In five countries (Bulgaria, Lithuania, Poland, Romania and Slovakia) the corresponding figure is higher than $90 \%$. In the minds of many Eastern Europeans transition to the market economy was combined with a higher standard of living. Experiencing the huge gap between their and the Western European quality of life elicited impatience for better life circumstances. Besides unemployment, low wages, high inflation rates and growing poverty, the chance for higher earnings abroad motivate many people in the transition countries to look for jobs in states offering higher incomes.

Pleasant people, with an average of $70 \%$, is the second most important aspect for Europeans. (See Figure 3) Applying data of the EVS, it cannot be concluded that pleasant people are more important to Eastern Europeans than they are to Northern and Western Europeans. On the contrary, regarding pleasant people, the average of 19 Northern and Western European countries is $73 \%$, while the corresponding figure in the $14 \mathrm{CEE}$ countries is $67 \%$. Central and Eastern Europeans also appreciate having nice colleagues, but for them job security is more important than a good workplace atmosphere. Most interesting is the fact that five CEE countries (Slovenia, Hungary, Croatia, Romania, Poland and Estonia) are way above average in the assessment of this aspect. This seems to fit the opinion that personal ties are just as important, or more important than the task in Eastern Europe. The workplace is not only an area for creating value added, but also a social net, where people can fulfil their social need for creating human relationships. As Figure 3 shows, pleasant people as a working condition aspect ranked third in CEE. 
The Global Leadership and Organizational Behaviour Effectiveness (GLOBE) survey also aims to discover the importance of human relations at work. The GLOBE is a cross-cultural research program based on data collected by 160 scholars from 60 countries. The idea came to Robert House (University of Pennsylvania) in 1991. Data collection was finalized in December 1997 (House 1998). There are nine cultural dimensions studied in GLOBE, the first six originate from the dimensions of culture identified by Hofstede (1980). 1. Uncertainty Avoidance 2. Power Distance 3. Collectivism I: Societal Collectivism 4. Collectivism II: In-Group Collectivism 5. Assertiveness 6. Gender Egalitarianism. 7. Future Orientation 8. Performance Orientation 9. Human Orientation (House et al. 2002).

Bakacsi et al. $(2002: 69,75)$ determined in the GLOBE survey that in the Eastern European cluster, which consists of Albania, Georgia, Greece, Hungary, Kazakhstan, Poland, Russia and Slovenia $\mathrm{a}^{5}$ human orientation is rated in the midrange, but there is a deep family and group cohesion and a high group orientation. The results of the GLOBE and the EVS thus mutually confirm and complete one another: having pleasant colleagues is the most important aspect after high salary and secure position. If pleasant people work together, strong group cohesion can develop.

Other studies conducted according to the cultural standard model ${ }^{6}$ also show a strong relationship orientation. "In Hungary workplace relationships are friendly. People find it indispensable to ensure a smooth work process. Workplace friendships do not only consist of personal conversations, but colleagues often spend their free-time together as well, or invite each other over to their homes" (Hofmeister/Tóth et al. 2005:8). "In Hungary it is very important to describe one's own relationship with others. Hungarian managers place more importance on their personal lives." (Danis/Parkhe 2002:435). In Borgulya's $(2000)^{7}$ German-Hungarian comparison, the German managers repeatedly pointed out the importance of personal relationships at work as a critical factor:

5 Other Eastern European countries such as Slovakia did not take part in the survey, and data from the Czech Republik could not been taken into account.

6 Alexander Thomas (1988), who developed the theory of cultural standards, defines them as the following: "Cultural standards combine all forms of perception, thinking, judgment and behaviour which people sharing a cultural background rate as normal, self-evident, typical and binding for themselves and for others". Thus, cultural standards regulate the way we interpret our own behaviour as well as the behaviour of others. They are highly significant for the mechanisms of perception, judgment and behaviour amongst individuals. (Kainzbauer/Brück 2000).

7 Between 1997 and 1999 Borgulya and colleagues conducted a survey at multicultural companies in Hungary using a combined method (quantitative and qualitative). Out of 134 respondents, 34 gave answers regarding the Hungarian-"German" (both Austrian and German) co-operations (Borgulya 2000). 
in errands and HRM decisions, for example, it is usually friendship and personal commitment that are often stronger than arguments based on facts. Szalay (2002:103) came to the same conclusion. During her interviews with Germans, the role of personal relationships at Hungarian workplaces was emphasised. Hungarians always take personal ties into account, moreover, old friends and relations act as a kind of capital. ${ }^{8}$ Similarly to the German-Hungarian comparison, the cultural standard survey examining German-Czech relations (Schroll et al. 2003) highlighted the personal orientation of the Czechs, more specifically that the relationship aspect is more important than the content aspect. ${ }^{9}$

\section{Figure 4. Importance of 'interesting job' and 'good job security'}
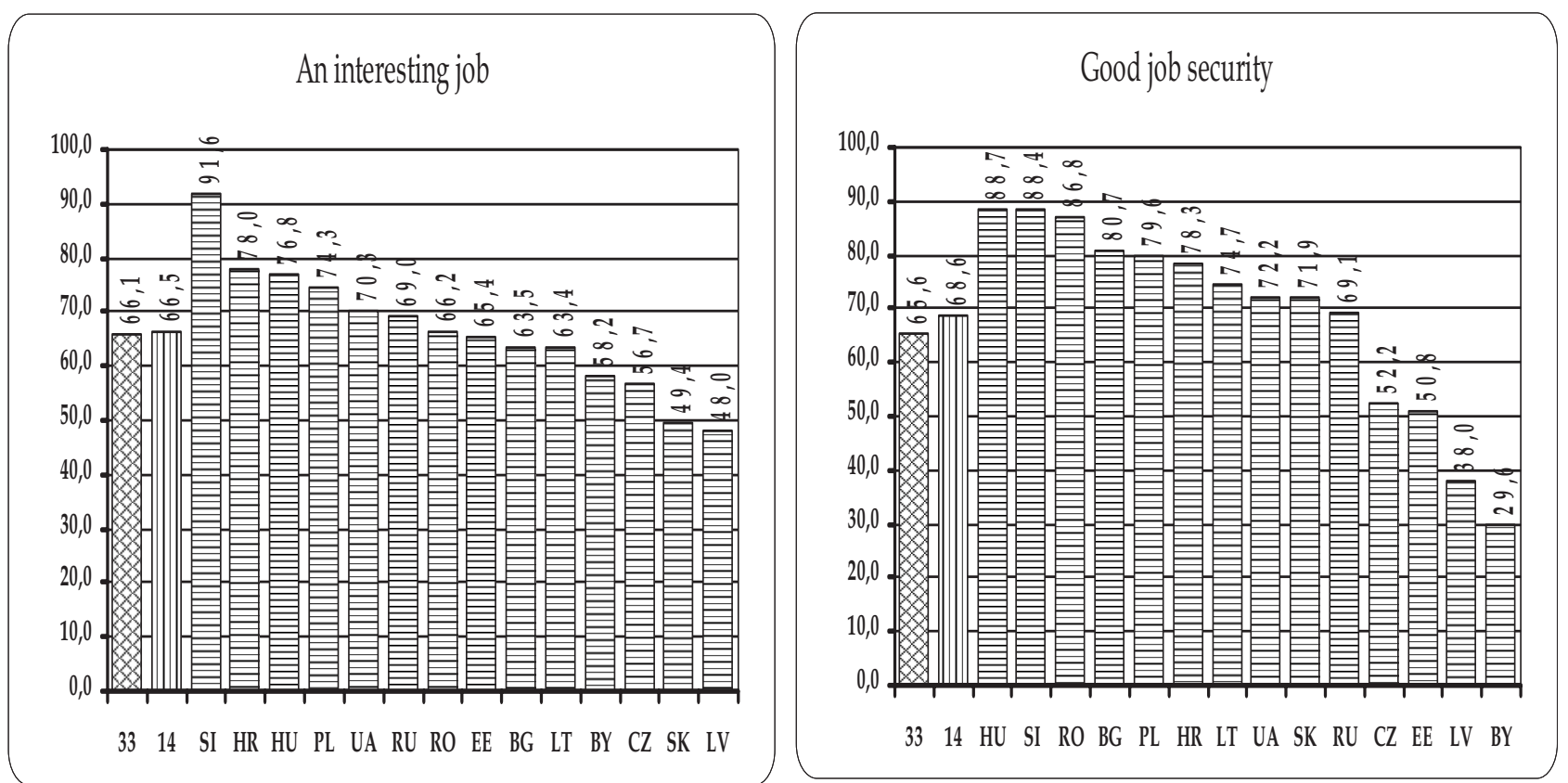

Source: EVS Source Book 1999/2000

8 Using the cultural standard model, Szalay interviewed 45 German and 30 Hungarian company heads and employees. Their leadership style patriarchal, but not too formal. "Hungarians believe that their boss knows everything best; they are bad at time management and keeping deadlines (minutes and hours are not a problem), they do not openly voice their opinions and take sides" (Szalay 2002).

9 Schroll et al. (2003) claim structure to be less important to the Czechs than it is to Germans. The Czechs also like to improvise and work simultaneously. Instead of complying with general rules, the Czechs prefer person-oriented control. They are less direct and explicit than Germans, but compared to them they are not as confident. It is interesting to see that Germans mentioned many traits similar to those listed for Hungarians, although in the EVS the two countries were placed in separate groups based on their work-related values. 
However, there are also countries where people are not really motivated by having nice colleagues: in Latvia, for instance, only $32 \%$ of the respondents listed this factor as an important one compared to $90 \%$ of Slovenians and $85 \%$ of Hungarians. Enjoying the process of wealth-creation belongs to the psychological proceeds of work. Interesting job was placed third on the list of European averages with 66\% (Figure 4), and for Eastern Europeans it is the fourth most important aspect of work after good pay, good job security and pleasant people.

With reference to Figure 4, big differences can be noted among the CEE countries: $92 \%$ in Slovenia means that nearly twice as many Slovenians appreciate an interesting job as Latvians. Hungary, Croatia and Poland also appear at the top of the list. It is hard to find a rationale for this difference in behaviour; further research on homo ludens could explore interesting findings.

Having secure employment is conceived as a crucial condition for Central and Eastern Europeans: ten countries scored higher than the European average. In the case of Hungary, Slovenia and Romania more than $86 \%$ of those questioned were of the opinion that good job security is important. (See Figure 4) By contrast, there is a group of countries that do not find this factor so influential: the Czechs, Estonians, Latvians and Belarusians.

\section{Figure 5. Importance of 'matching abilities' and 'achieving something'}

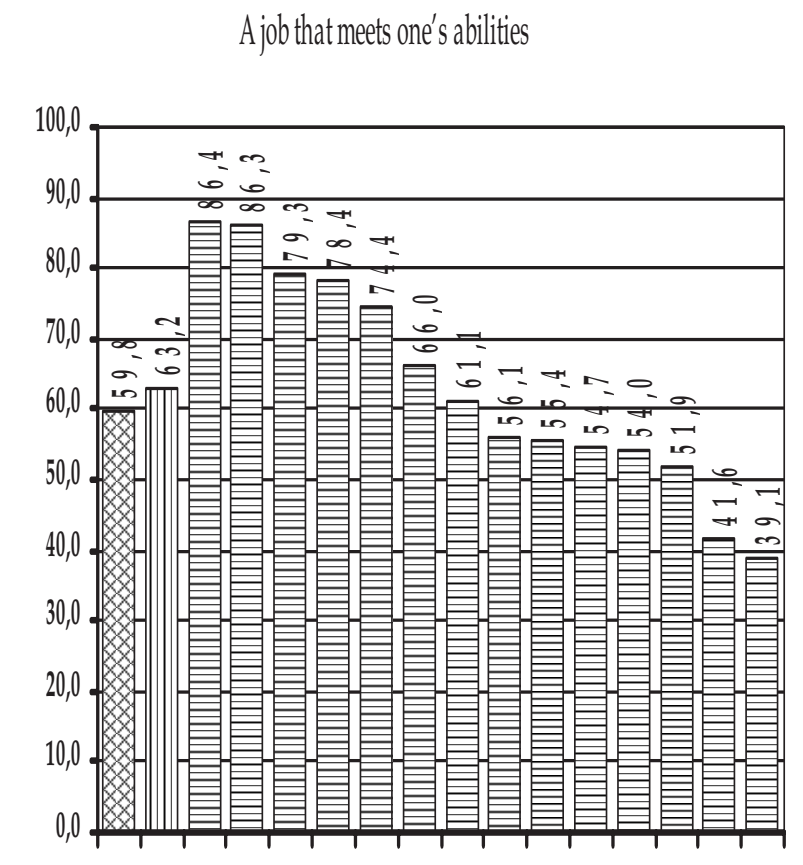

3314 SI HU RO BG HR PL UA CZ SK EE RU LT LV BY

\section{A job in which you can achieve}

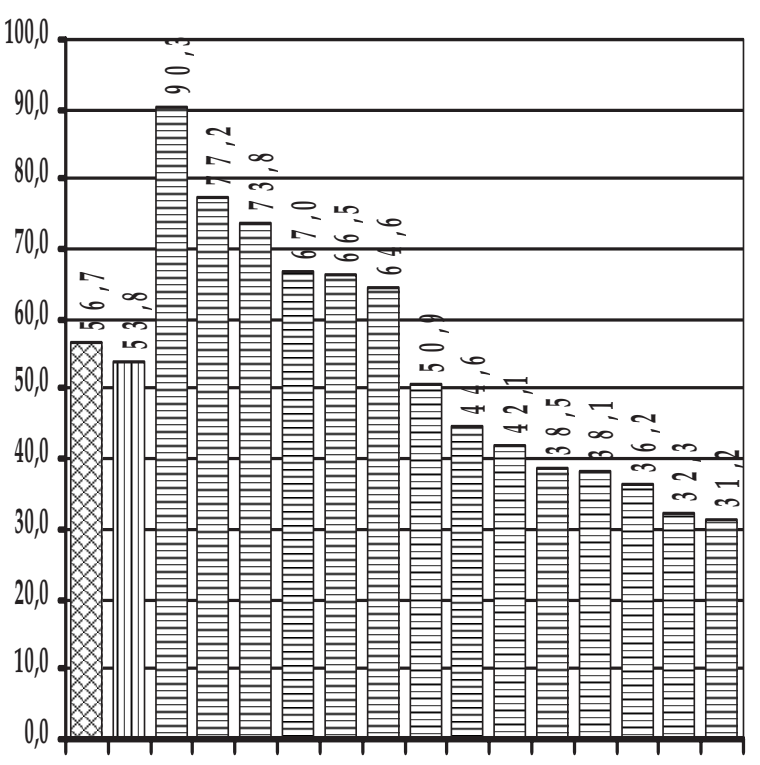

33 14 SI HU RO HR PL BG UA EE LT RU CZ SK LV BY 
As mentioned above, unemployment is a new phenomenon in CEE countries. The societies are not prepared to manage the psychological consequences of the problem. Consequently, unemployment poverty very often goes together with depression, mental illness and alcoholism. What used to be natural before the transition, namely having a secure job, became appreciated value after the political and economic changes. Besides a certain national feeling some anxiety about losing jobs can be identified in the answers of Central and Eastern Europeans given in agreement to the statement "when jobs are scarce, employers should give priority (to own nationals) over immigrants" (Halman 2001: 69). This is the opinion of more than $94 \%$ of Lithuanians, more than $90 \%$ of the Poles, $90 \%$ of Hungarians, $88 \%$ of the Slovaks and Croatians, while only $11 \%$ of Swedes. Among the rest of the aspects there is great deviation among Eastern European countries.

As shown in Figure 5, for Slovenians, Hungarians and Romanians it is vital that a job matches one's abilities and that one can achieve something through work. It is nearly three times as important to them as to Latvians and Belarusians. Slovenians and Hungarians seem to appreciate the psychological impact of work, which is supported by our previous observation regarding these nations' assessment of the importance of pleasant colleagues and an interesting job.

\section{Figure 6. Importance of 'good hours' and 'meeting people'}
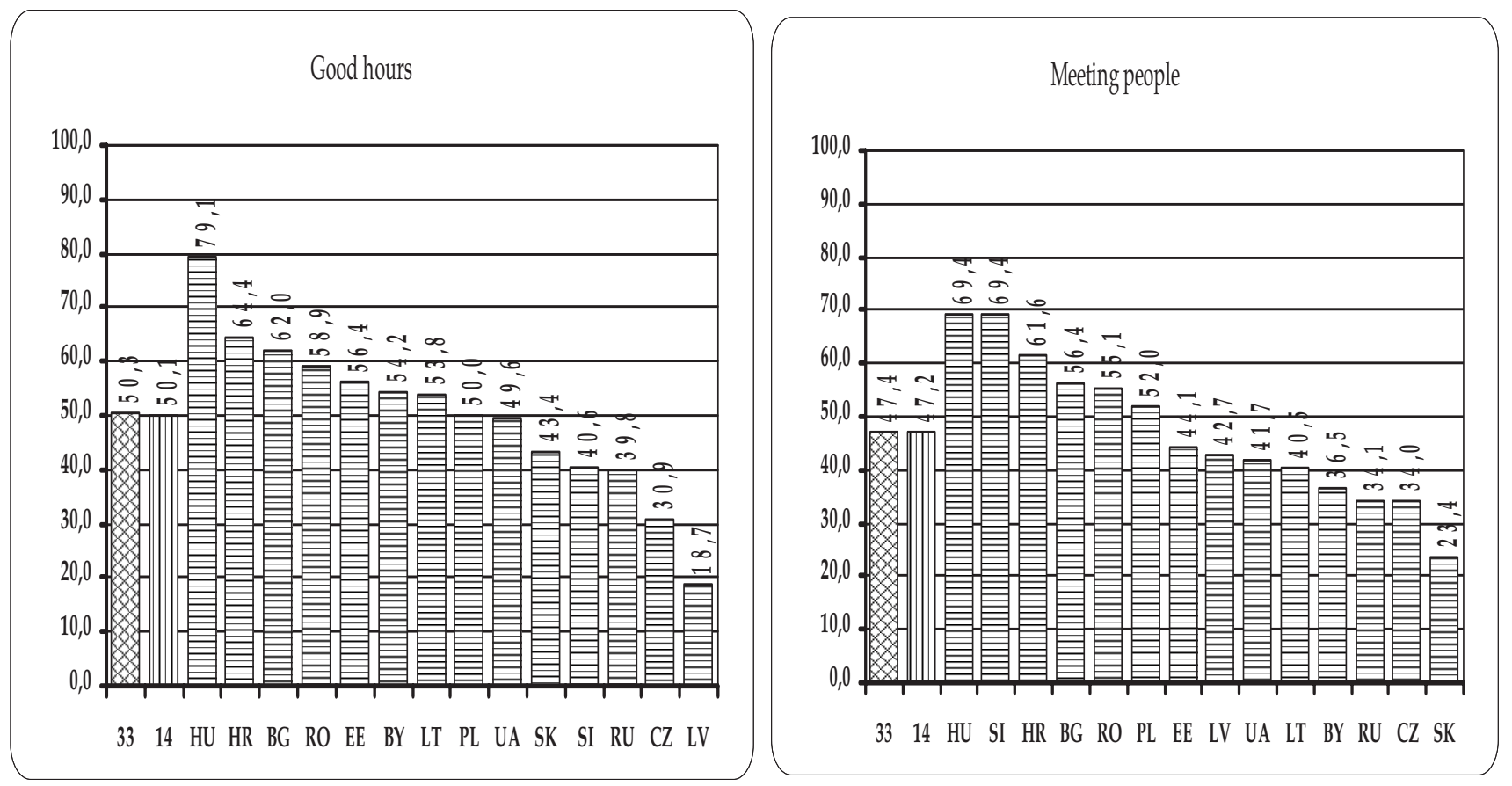

Source: EVS Source Book 1999/2000 
Figure 6 demonstrates the categories of good hours and meeting people. With Hungary scoring the highest in both cases, the playing field is diversified. In countries where people typically do not have only one job (like in Hungary), time management is the main point in organizing work. Hungarian families are typically based on two wage-earners. Women, therefore, must find a balance between work and household, which enforces them to favour jobs with favourable hours.

One could think that those who like to work together with pleasant people would also say work is a good chance for meeting people. But as Figure 6 shows the possibility of meeting people is much less desired than having nice colleagues. There is no significant difference between CEE countries and the rest of Europe: the averages are almost the same. Hungarians and Slovenians enjoy socialising at work the most: they scored the highest in this aspect again.

Initiative is an engine in a company: it produces new ideas to help problem solving and supports creativity. Figure 7 suggests that this aspect of work is evaluated in the CEE countries very differently: we can observe the most significant diversities regarding this aspect. While Slovenians attach great importance to an opportunity to use initiative, Latvians neglect it (Figure 7).

Figure 7. Importance of 'an opportunity to use initiative' and 'a job respected in general'

\section{An opportunity to use initiative}

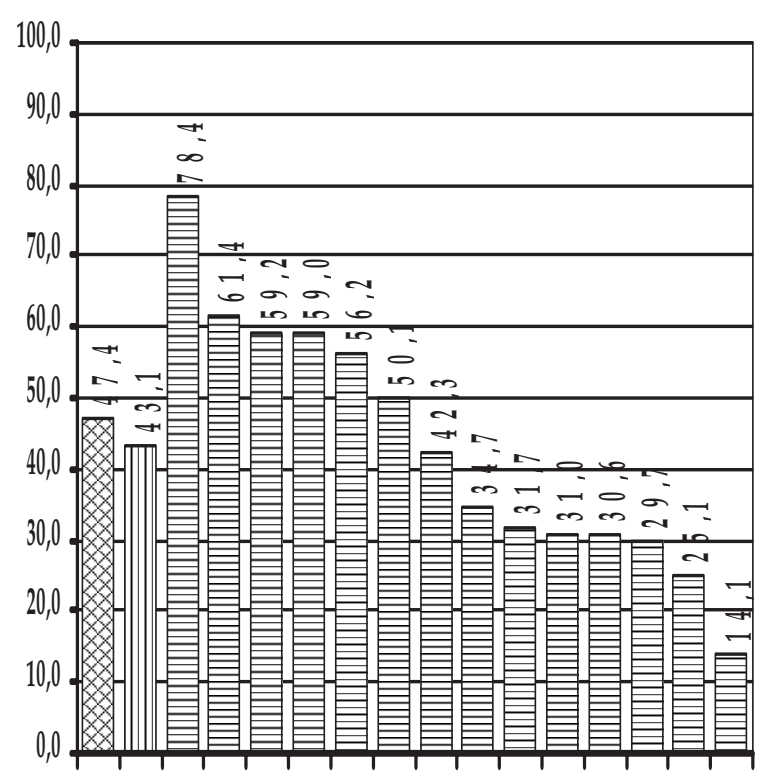

3314 SI HU HR RO PL BG UA EE LT SK RU CZ BY LV
A job respected by people in general

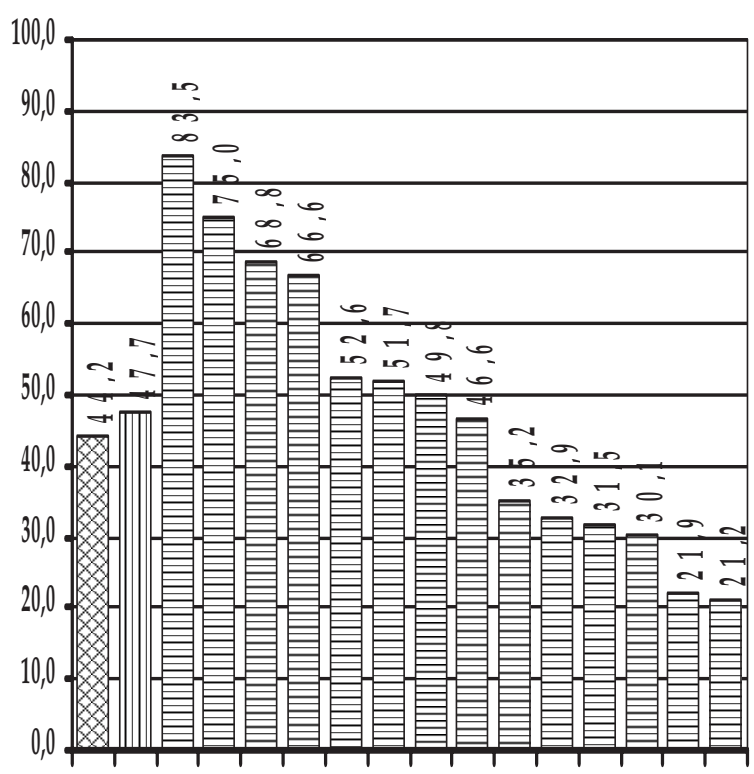

$3314 \mathrm{HU}$ SI RO PL UA BG HR RU CZ LV EE BY SK LT 
Neither is respect gained by work important to some Eastern European countries such as Slovakia and Lithuania, but it is crucial for some others like Hungary and Slovenia. In Hungary many underpaid professionals (physicians, teachers) who are respected by society regard this respect as a kind of moral compensation for their low salaries.

Having a responsible job is for many people a challenge, a self-measurement and an important component of their self-esteem. But not in all CEE countries do people desire to undertake risk. This may be the case in Belarus, Latvia and Estonia in contrast with Hungary and Slovenia, where more than $70 \%$ of the respondents found responsibility important. (See Figure 8).

Figure 8. Importance of 'a responsible job' and 'a useful job for society'
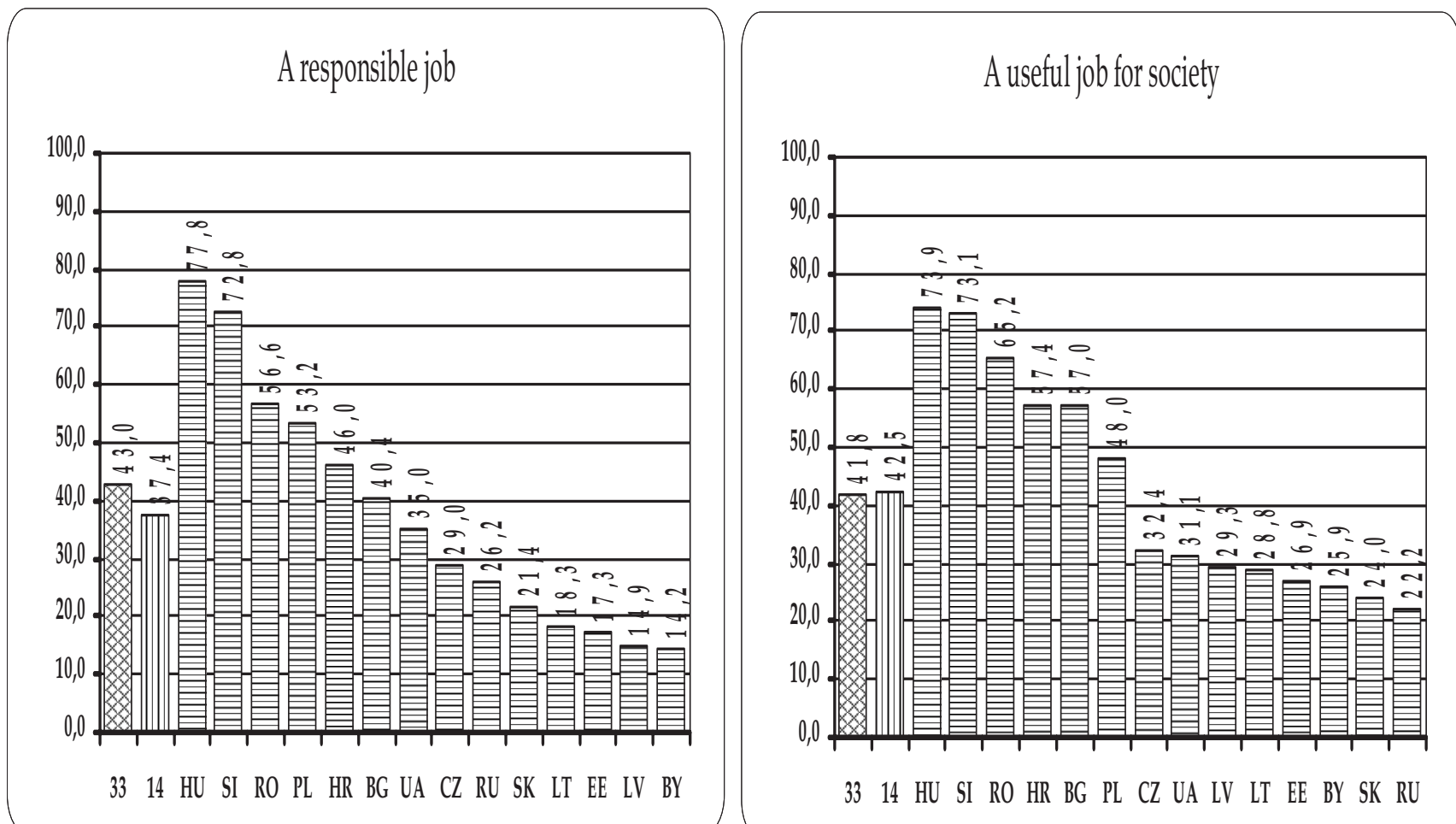

Source: EVS Source Book 1999/2000 
Figure 9. Importance of 'not too much pressure' and 'generous holidays'
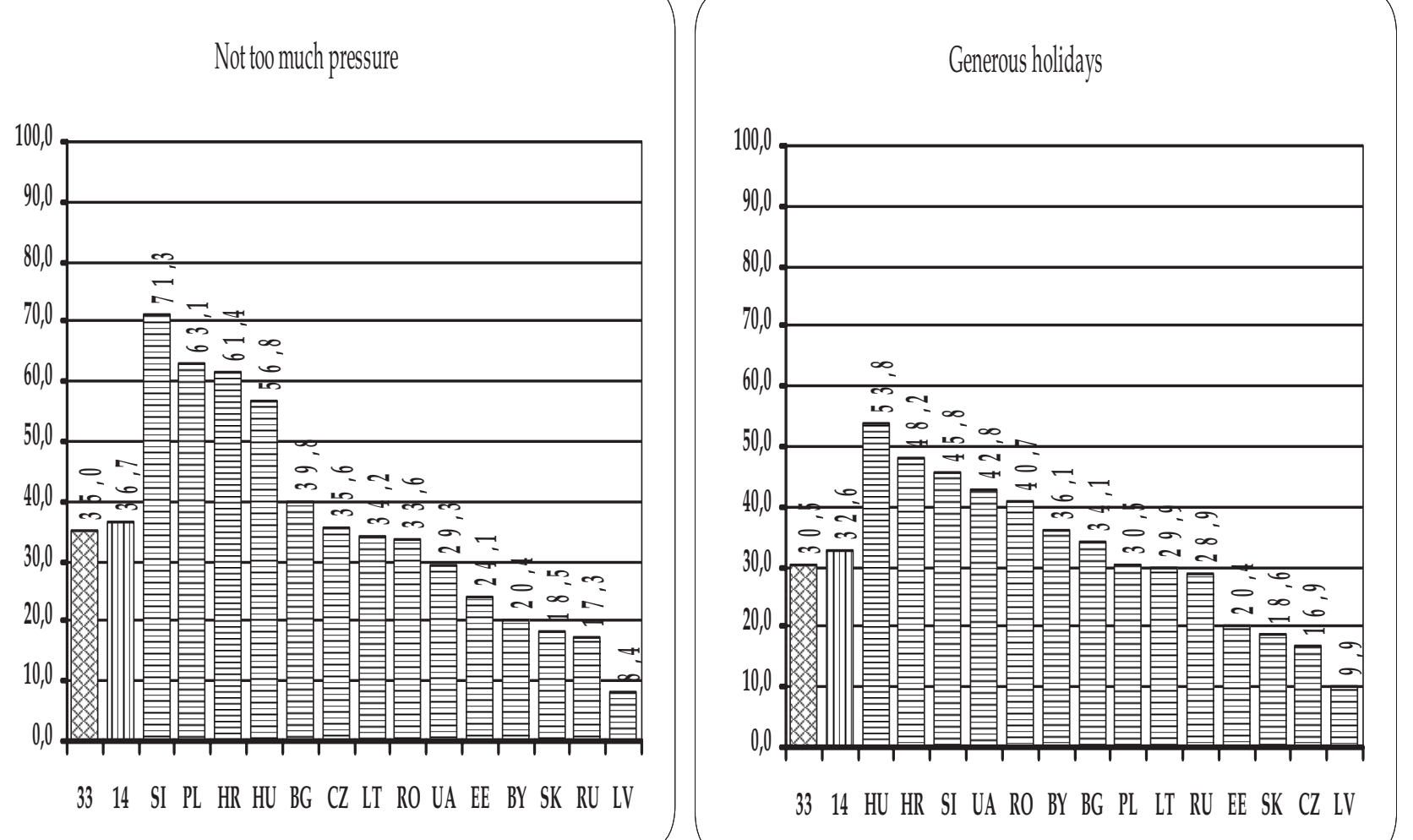

Source: EVS Source Book 1999/2000

While a useful job for society only ranked twelfth in the European average, it was placed far above the average in six CEE countries: in Hungary, in Slovenia, in Romania, in Croatia and in Bulgaria. By contrast, the figure remained below the average in the other eight countries. In Russia only $22 \%$ of the respondents were of the opinion that making a useful contribution to society is important to them.

The answers regarding the tolerance of stress at the workplace again reflects a division among the nations. As shown in Figure 9, having not too much pressure, i.e. a stress-free job is important to Slovenians, Poles, Croatians and Hungarians, but among Latvians only $8 \%$ feel this way (Figure 9). The least important aspect for Europeans is generous holidays with an average of only $30 \%$. As we can see from the results, CEE countries are not homogenous in this respect either. For example, 54\% of Hungarians find it important, as opposed to the $10 \%$ of Latvians, who consider this of least importance.

\section{Similarities among CEE-countries regarding important aspects of work}

The analysis of the EVS data regarding the work-related values of CEE countries indicates a diversification of opinions among nations. Comparing all 
work-related values, we can identify two groups forming among CEE countries. These two groups are: Slovenia, Hungary, Croatia, Poland, Romania on the one hand, and Slovakia, the Czech Republic, Latvia, Lithuania on the other, occasionally joined by Estonia and Belarus. (See Figures 10 and 11)

Slovenia and Hungary stand out from the CEE countries with their high results and not far behind are Croatia, Poland and Romania. As the members of this subgroup agree on how important the aspects good pay, pleasant people, good job security, good chances for promotion, a job respected by people in general, an opportunity and to use initiative, meeting people, an interesting job and a job that meets one's abilities are, we can call them a group with high motivation variability (See Figure 10). It is also noteworthy that their values scored above the European average.

Hungarians and Slovenians find more aspects important than the European average. They lead in more than one factor. With regard to the aspects observed, they give nearly everything equal value: job security, possibility for promotion, social respect for their job, a useful job, interacting with other people, and a responsible job. Though being a post-socialist country, Hungary does not meet the description foreigners have given about its citizens until now: that Hungarians do not like responsibility in their jobs, and try to avoid highly responsible situations (Simon/Davis 1995). Hungarians find it far more important $(83 \%)$ to be respected by others at the workplace than Latvians (21 $\%)$. This is the category where we find the greatest deviation from the European average (Hungary: 83\% Europe-33: 44\%). Good salary is a very important factor for Hungarian people too, as demonstrated also by the findings of the survey STRATOS conducted at Hungarian companies (Borgulya et al. 1996). However, to members of an organization with a knowledge-oriented culture, intellectual values seem to be more important than material values (Dobrai/Sümegi 2005). Comparing the CEE countries, many similarities can be found between Hungarians and Slovenians in valuing work-related aspects.

At the same time, the members of the other group, i.e. Slovakia, the Czech Republic, Latvia and Lithuania agree on how unimportant the aspects not too much pressure, good chances for promotion, a job respected by people in general, a useful job for society, a responsible job, an opportunity to use initiative, generous holiday are. They only accorded high importance to good pay and good job security. This group can be called the group with low motivation variability. The values in this group are mostly below the European average. 
Figure 10. Group with high motivation variability

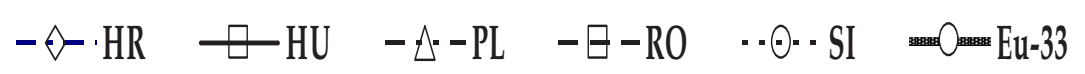

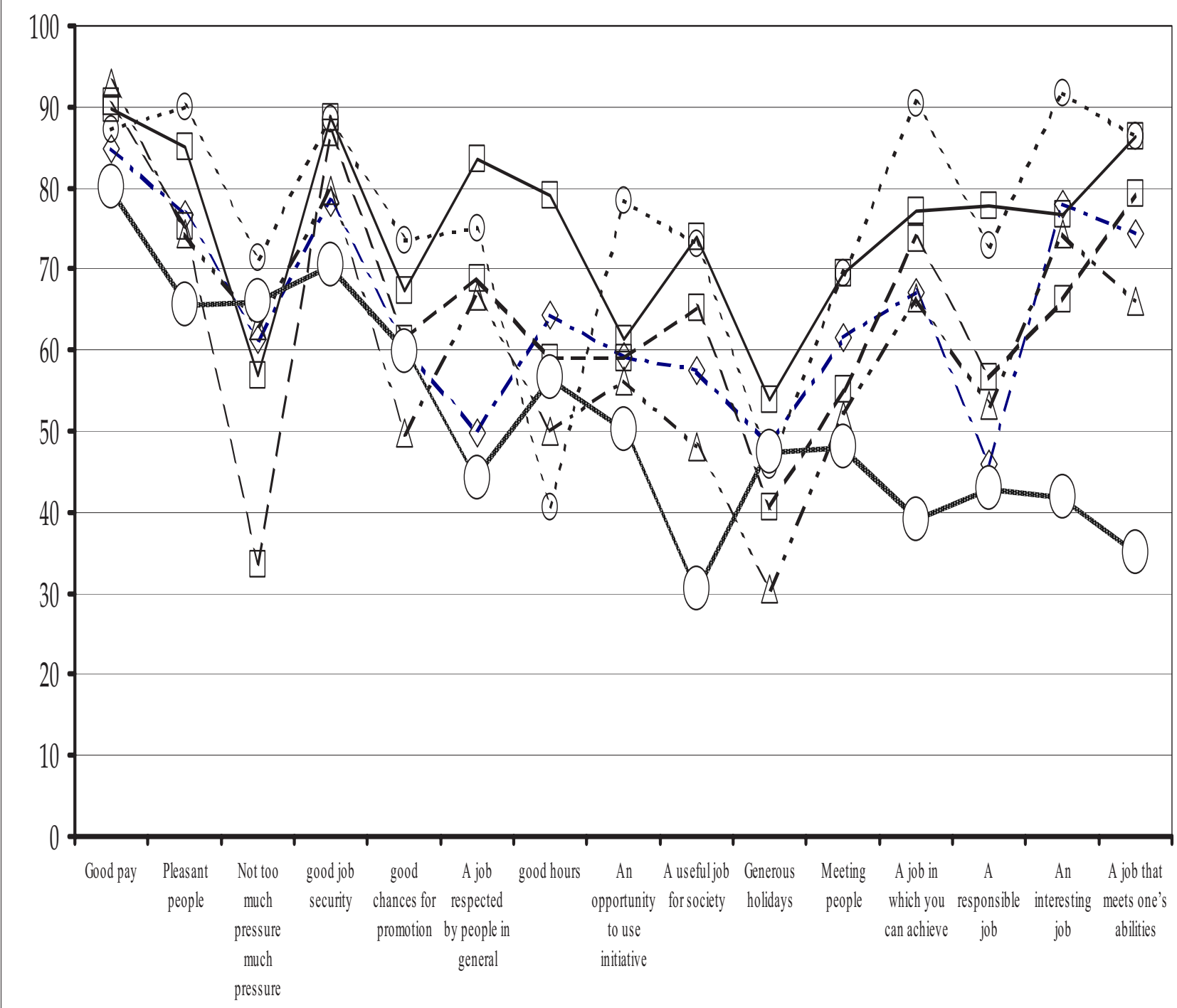

Source: EVS Source Book 1999/2000 
Figure 11. Group with low motivation variability

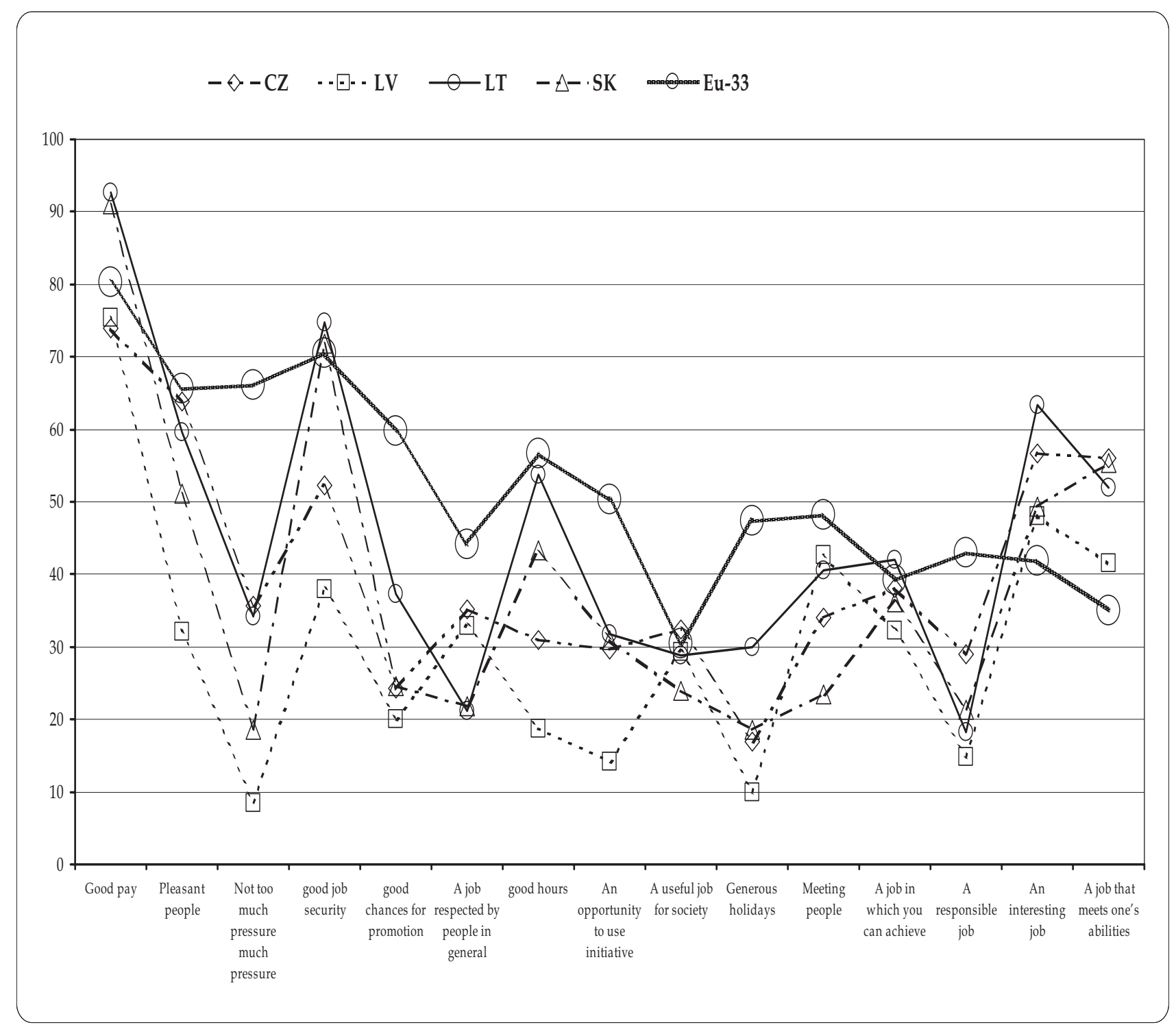

Source: EVS Source Book 1999/2000

\section{Following instructions at work}

Many cultural conflicts at work have their origin in the relationship between superiors and subordinates, especially in multicultural companies. Where are the limits of an employee's freedom to act? Does he want to be instructed by his boss? Does the line manager help him by giving clear instructions, or is the boss interested only in the outcome? Hofstede's dimension of power distance is also built around these questions. In the EVS respondents had to choose from two options: People have different ideas about following instructions at work. Some say that one should follow the superior's instructions even when one does not fully agree with them. Others say that one should follow one's superior's 
instructions only when one is convinced that they are right. Which of these two opinions do you agree with?

The European averages suggest that the number of those who would blindly follow instructions is almost equal to those who would defy orders unless they are convinced of the justness of the instructions. (See Figures 12 and 13) According to Hofstede (1980), if power distance is large, employees will not question the superior's instructions. Taking into account the results of GLOBE (House 1998; House et al. 2002; Bakacsi et al. 2002) power distance in the Eastern European cluster is high.

As shown in Figure 12, Hungarians are those who most often follow instructions even if they do not agree with them. This seems to be in line with the findings of Szalay (2002: 103), who points out that the leadership style of Hungarian managers is patriarchal, but not over-formal. "Hungarians believe that their boss knows everything best". Borgulya (2000), however, comes to the conclusion that Hungarians do not say no openly, instead they quietly sabotage what they do not agree with.

\section{Figure 12. Follow instructions}

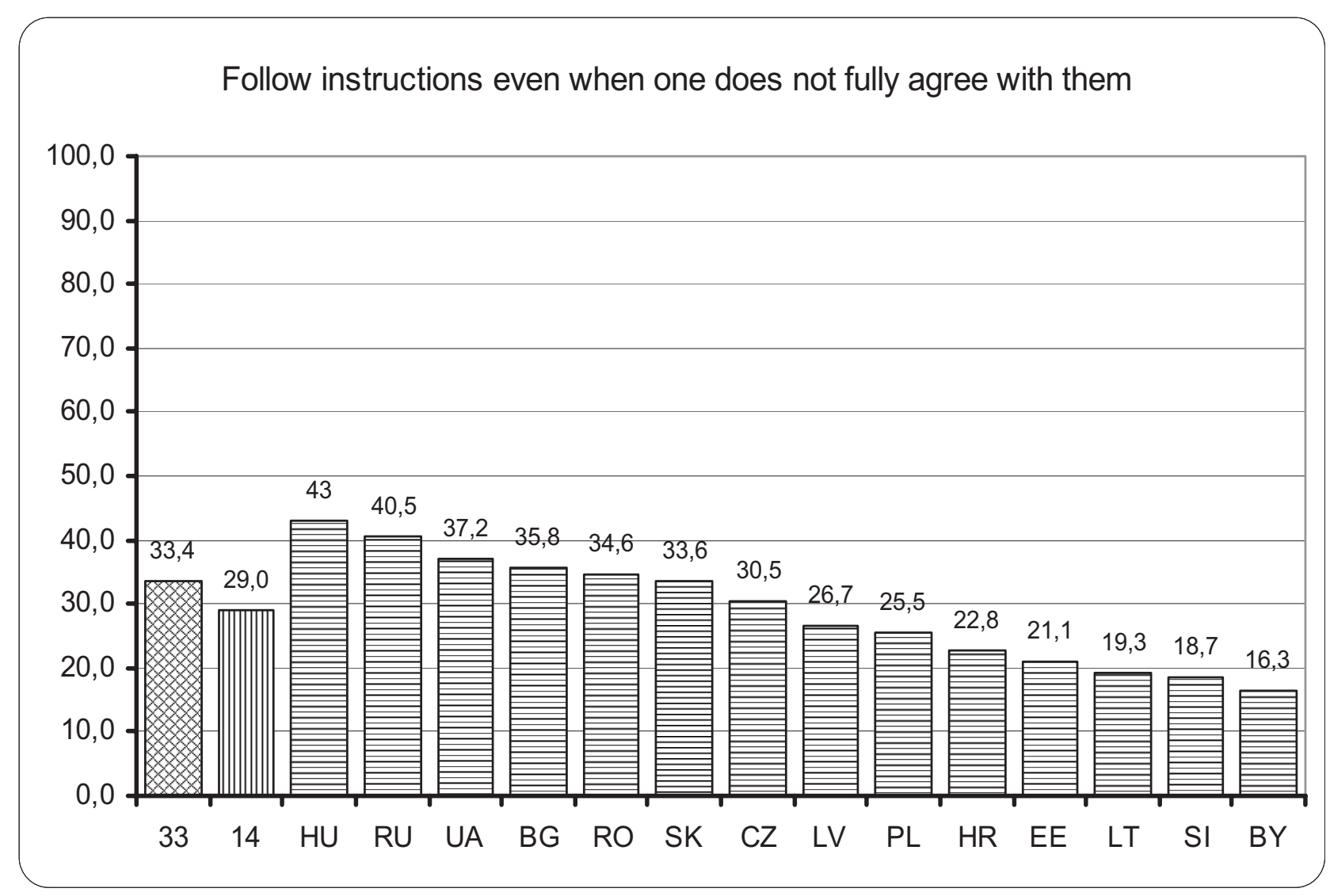

Source: EVS Source Book 1999/2000 
It may easily happen that Hungarians do not confront their leaders openly, but express their disagreement by quietly not following the instructions. Russia, Ukraine, Bulgaria, Romania and Slovakia exceed the European average as well. (By contrast, there are again countries that take a different path of attitudes: only $16 \%$ of Belarusians, $19 \%$ of Slovenians, and $19 \%$ of Lithuanians would never question their superior's instructions.) We assume this has something to do with a higher level of authority. Danis and Parkhe analyze the Hungarian situation in the following way: "Hungarian managers were generally more autocratic and more comfortable with the open use of power than their Western counterparts; (Hungarian) managers have a much more directive role compared to those in Germany. (In Hungary) if the managers say something, their subordinates follow. The managers have a much more powerful role with respect to telling the operators what they have to do. An Austrian characterized his Hungarian partner's parent company as a 'personality cult', which revolved around the allpowerful chief executive officer." (Danis/Parkhe 2002:437).

Figure 13. One should be convinced

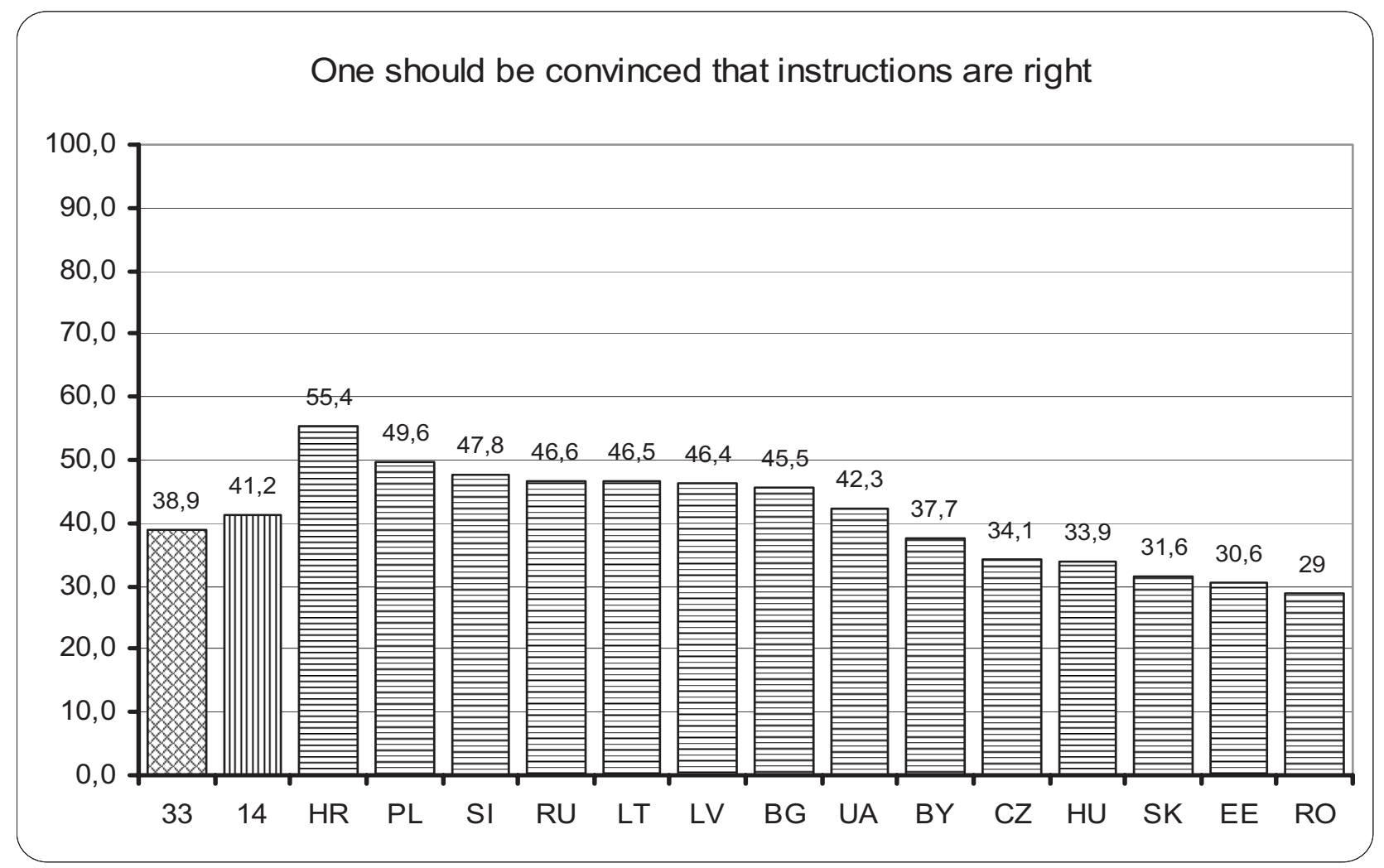

Source: EVS Source Book 1999/2000

In our view, besides the autocratic leadership style, the Hungarian mentality towards avoiding open confrontation could also be reflected in the high rate of positive answers. Hungarian proverbs, for example, warn against voicing one's opinion: "Mondj igazat, és betörik a fejed" (All truth will not bear telling). "Ne 
szólj szám, nem fáj fejem." (A still tongue makes a wise head.) Besides this mentality there are also pragmatic factors preventing employees from questioning their superiors: in Hungarian organizations it is still common for superiors to share only little or selected information. Thus, employees are not wrong to believe that since their superiors know more, they can better assess the situation and decide what the right action to take is.

Fink and Meierewert (2004:74) claim that withholding information is typical of Eastern Europeans. "Decisions are delegated to supervisors who are authorised to make decisions. Information is not easily passed on or collected." ${ }^{10}$ However, this seems to be disproved by Slovenia and Poland: they belong to the Eastern European cluster, yet in these countries only $19 \%$ and $25 \%$ of employees follow instructions without questioning them. (It should be noted that only $28 \%$ of Germans question their superior's instructions.)

Figure 13 demonstrates that more than half of Croatian respondents $(55 \%)$ would only follow instructions if they were convinced it was the right action to take, in other words, when in doubt, they would re-evaluate the orders given. The percentage of Poles and Slovenians who wanted to be convinced before acting is also higher than the European average (Figure 13). Considering all European countries and their agreement with this statement, only the Finns represent a higher ratio (59\%) than the Croatians.

\section{Conclusion}

This paper examined the work-related values of fourteen CEE countries. Applying the database and some selected data of the third wave of the European Values Study we have pointed out that the most important component of life, both for the people of 33 European countries and for the 14 CEE members, is family followed by work. Among job-related aspects, Central and Eastern Europeans give preference to high salaries and wages, job security, pleasant colleagues and an interesting job, followed by other criteria as presented below. (Figure 14)

10 Fink and Meierewert examined the results of Eastern European co-operations from the perspective of Austrians and came to the conclusion that their work-related value standards are risk aversion, priority setting by supervisors, working in collectives, harmony seeking and 'saving own face'. From these cultural standards, the authors derived a number of time management problems typical of Eastern Europeans. These are the slow speed of solving tasks, extreme length of negotiations and decision-making processes, and wasting the time of their counterparts (Fink/Meierewert 2004:61). 
Figure 14. Ranking of 15 aspects of work

\begin{tabular}{|c|c|c|c|}
\hline \multicolumn{2}{|c|}{ Ranking of aspects of work, Eu-33 } & \multicolumn{2}{|c|}{ Ranking of aspects of work, Eu-14 } \\
\hline Good pay & 80,2 & Good pay & 87,4 \\
\hline Pleasant people & 70,5 & Good job security & 68,6 \\
\hline An interesting job & 66,1 & Pleasant people & 66,7 \\
\hline Good job security & 65,6 & An interesting job & 66,5 \\
\hline A job that meets one's abilities & 59,8 & A job that meets one's abilities & 63,2 \\
\hline A job in which you can achieve & 56,7 & A job in which you can achieve & 53,8 \\
\hline Good hours & 50,3 & Good hours & 50,1 \\
\hline Meeting people & 48,2 & A job respected by people in general & 47,7 \\
\hline An opportunity to use initiative & 47,4 & Meeting people & 47,2 \\
\hline A job respected by people in general & 44,2 & An opportunity to use initiative & 43,1 \\
\hline A responsible job & 43,0 & A useful job for society & 42,5 \\
\hline A useful job for society & 41,8 & Good chances for promotion & 41,7 \\
\hline Good chances for promotion & 39,2 & A responsible job & 37,4 \\
\hline Not too much pressure & 35,0 & Not too much pressure & 36,7 \\
\hline Generous holidays & 30,5 & Generous holidays & 32,6 \\
\hline
\end{tabular}

Source: EVS Source Book 1999/2000

By comparing the $14 \mathrm{CEE}$ countries, we could identify similarities but also remarkable differences regarding work-related preferences. A similar importance is attached in all CEE countries to the importance of work and high salaries/wages but great divergence can be found concerning:

- the importance of the opportunity to use initiative,

- the importance of respect for a certain job in society,

- whether the job is useful for society,

- whether it requires responsibility,

- whether it involves much pressure.

Our analysis has revealed that there are subgroups within the CEE countries: a group with 'high motivation variability' that considers a lot of aspects of work important, and another one with low motivation variability. Slovenia and Hungary stand out from the Eastern European countries with several motivating aspects, and not far behind are Croatia, Poland and Romania. The members of these subgroups agree on the importance of the following aspects: good pay, pleasant people, good job security, good chances for promotion, a job respected by people in general, and an opportunity to use initiative, meeting people, an interesting job and a job that meets one's abilities. At the same time, the other group, represented by Slovakia, the Czech Republic, Latvia and Lithuania, agree on how unimportant the aspects of not too much pressure, good chances for promotion, a job respected by people in general, a useful job for society, a 
responsible job, an opportunity to use initiative, and generous holiday are. They only accorded high importance to good pay and good job security. This group can be called the group with low motivation variability. The values in this group are mostly below the European average.

The attitudes towards superiors vary from country to country. Many Hungarians follow their superior's instructions even if they do not agree with them. The same behaviour was found in Russia, Ukraine, Bulgaria, Romania and Slovakia, whereas in Belarus, Slovenia and Lithuania employees would mostly question their superior's instructions if they do not agree with them.

\section{References}

Arts, W./Hagenaars, J./Halman, L. (2003): The Cultural Diversity of European Unity. LeidenBoston: Brill.

Bakacsi, Gy./Takács, S./Karácsonyi, A. /Imrek, V. (2002): Eastern European Cluster: tradition and transition, in: Journal of World Business, 37, 1, 69-80.

Borgulya, Iné/Bencze, V./Kiss, T. (1996): A kis- és középméretü vállalatok értékrendje, stratégiai magatartása. (The value system and strategic behaviour of the small and medium-sized enterprises), in: Marketing and Menedzsment, 6, 30-38.

Borgulya, Iné (2000): A magyar menedzserek és az interkulturális feladatok. OTKA kutatási jelentés (Hungarian Managers and Intercultural Tasks. OTKA - Research Report), Pécs: PTE.

Brück, F./Kainzbauer, A. (2000): Cultural Standards Austria - Hungary, in: Journal of Cross Cultural Competence and Management, Frankfurt: IKO Verlag, 73-103.

Dobrai-Sümegi, K. (2005): Knowledge Oriented Organizational Culture and Managing Organizational Knowledge. Proceedings of the Conference on "Intercultural Knowledge Management. Challenges of Eastern and Western Europe" (Wirtschaftsuniversität Wien, November 2005). In print.

Fink, G./Meierewert, S. (2004): Issues of time in international, intercultural management: East and Central Europe from the perspective of Austrian managers. JEEMS, 9, 1, 6184.

Halman, L. (2001): The European Values Study: A Third Wave. Source book of the 1999/2000 European Values Study Surveys. Tilburg: EVS, WORC, Tilburg University.

Harris, Ph.R./Moran, R.T. (1996): Managing Cultural Differences. (Fourth Edition) HoustonLondon: Gulf Publishing Company.

Hofmeister-Tóth, Á./Kainzbauer A./Brück F./Neulinger, Á. (2005): Kulturális értékek, kulturális dimenziók és kulturális standardok. (Cultural Values, Cultural Dimensions and Cultural Standards), in: Vezetéstudomány, 34, 2, 2-15.

Hofstede, G. (1980): Culture's Consequences: International Differences in Work-related Values. Beverly Hills, California: Sage 
House, R./Javidan, M./Hanges, P./Dorfman, P. (2002): Understanding cultures and implicit leadership theories across the globe: an introduction to project GLOBE, in: Journal of World Business, 37, 1, 3-10.

House, R. (1998): A Brief History of GLOBE, in: Journal of Managerial Psychology, 13, 3/4, 230-240.

Kainzbauer, A./Brück, F. (2000): Cultural Standards Austria - Hungary, in: Journal of CrossCultural Competence and Management. 2, Frankfurt: IKO-Verlag, 73-96.

Schroll-Machl, S./Novy, I. (2003): Tschechische und deutsche Kulturstandards in der Wirtschaftkooperation. Firmenkultur, Prag: Goethe-Institut, 7-24.

Simon, L./Davis, G.(1995): Cultural, social and organizational transition: The consequences for the Hungarian manager. in: Journal of Management Development. 14, 10, 14-31.

Szalay, Gy. (2002): Arbeit und Kommunikation in deutsch - ungarischen Teams. Budapest: Goethe Institut Inter Nationes, Deutsch-Ungarische Industrie- und Handelskammer.

Thomas, A. (1988): Interkulturelles Lernen im Schüleraustausch, SSIP-Bulletin, 58, Breitenbach, Saarbrücken.

Traser, U./ Venables, T. (2008): Who's afraid of the EU's latest enlargement: ECAS, Bruxelles. http://www.ecas.org

Varga, K. (1983): Szervezeti kultúránk koordinátái. (The Coordinates of Our Organizational Culture), in: Ergonómia, 3, 21-38. 